\title{
Leadership with Chinese Characteristics
}

\author{
Peter Marcus Kristensen ${ }^{1}$ Pippa Morgan² $^{2}$
}

Received: 29 November 2017/ Accepted: 18 December 2017/Published online: 8 January 2018

(C) Fudan University and Springer Nature Singapore Pte Ltd. 2018

\section{Leadership Voids and World Disorder}

The political underpinnings of the 'US-led liberal international order' are increasingly under stress. The United States under President Trump has signaled a retreat from multilateralism, international cooperation, and its global leadership responsibilities. As the administration heralds in a more nationalist and even isolationist grand strategy, a more transactionalist approach to alliance, withdrawal or renegotiation of free trade agreements such as TPP, TTIP, and NAFTA, the Paris Accords on climate change, the Iran nuclear deal, and organizations like UNESCO, most observers have started to question whether the United States will continue to play the global leadership role and uphold the institutions and norms of the international order it has installed in the aftermath of World War II. The 'Make America Great Again' policy has, ironically, contributed to a pervasive sense that the 'American century' is on the wane-among both allies and rivals. In the introduction to these two special issues on international leadership, Ole Wæver and Chen Zhimin raised the pertinent question of who then, if anyone, will take leadership?

One, quite prevalent, view is that such leadership vacuums will almost automatically fill. As UN Secretary-General Antonio Guterrez put it, "When someone leaves space, that space is always occupied by others." ${ }^{1}$ At the moment,

\footnotetext{
1 'Somini Sengupta, 2017. "U.N. Chief Warns U.S. of Risks of Rejecting Leadership Role," New York Times, June 20. https://www.nytimes.com/2017/06/20/world/americas/united-nations-secretary-generalantonio-guterres.html.
}

Pippa Morgan

p.morgan963@outlook.com

Peter Marcus Kristensen

pmk@ifs.ku.dk

1 Department of Political Science, University of Copenhagen, Copenhagen, Denmark

2 School of International Relations and Public Affairs, Fudan University, Shanghai, China 
most eyes are of course on China as the potential power that will 'step into the void'. Indeed, China, and President Xi Jinping in particular, has been starting to position itself as a natural successor. Not incidentally, the United States' disengagement from its global leadership role and growing unwillingness to provide public goods and accept free riding comes at a time when China is re-emerging to a strong global position and asserting itself on the global stage. There is wide consensus that as the US has been moving towards "leading from behind" and now perhaps stopped leading at all, Chinese foreign policy has undergone a shift from "keeping a low profile" to "striving for achievement" (Yan 2014; Zeng 2017). A more activist, if not assertive, foreign policy where China aims to position itself, as President Xi Jinping put it at the 19th Party Congress, "at the center of the world stage", is emerging. ${ }^{2}$ Much of this 'stepping into the void' is rhetorical, of course, and the Chinese leadership has not missed many opportunities to portray itself as the antithesis to Trump's America. In the face of America's disengagement from multilateral agreements and institutions, Xi Jinping has continuously reinforced China's commitment to global leadership, globalization, multilateralism, free trade, and economic cooperation. Most notably his speech at the World Economic Forum in Davos-whose theme was "responsive and responsible leadership"-aimed to reassure, mostly European, elites that China will defend globalization and free trade if the United States will not. As the United States declared its intended withdrawal from the Paris Climate Accords, EU leaders and Chinese Premier Li Keqiang collectively reaffirmed their commitment to the agreement. When Trump announced the withdrawal from UNESCO, the Chinese reaffirmed the importance of UNESCO. Most recently, the 19th Party Congress signaled that China is aiming to take on a greater leadership role. President Xi Jinping pronounced the start of a "New Era", characterized by "Chinese wisdom and a Chinese approach to solving the problems facing mankind." 3 Ending China's decades of insisting that each country should follow its own path, Xi's speech offered China's model as "a new option for other countries and nations who want to speed up their development." ${ }^{4}$ In doing so, President Xi added the rhetoric to match China's increasingly confident and 'leaderly' international behavior. There is also evidence that this is more than rhetorical, that China is actually stepping up its global leadership on issues such as free trade, peacekeeping, infrastructure development and climate change. China's Belt and Road Initiative (BRI), the internationalization of the renminbi, proactive stance on climate change, growing military presence abroad and seemingly undisturbed territorial revisionism in the South China Sea exemplifies a fresh confidence that signals a break from Deng Xiaoping's cautious mantra of tao guang yang hui, (keeping a low profile) which has guided China's foreign policy since reform and opening.

\footnotetext{
${ }^{2}$ Xinhua, 2017. "Xi Jinping: Leader of China's great revival," March 13. http://news.xinhuanet.com/ english/2017-03/13/c_136125706.htm.

3 “Opening ceremony of the 19th CPC National Congress". 2017. http://live.china.org.cn/2017/10/17/ opening-ceremony-of-the-19th-cpc-national-congress/.

4 “Opening ceremony of the 19th CPC National Congress". 2017. http://live.china.org.cn/2017/10/17/ opening-ceremony-of-the-19th-cpc-national-congress/.
} 
The view that vacuums tend to fill and that China seems to be the matter now filling the geopolitical spaces left by the United States is misleading, however. One of the main problems with this contemporary commentary on global leadership —or the lack thereof-is that it proceeds from the assumption that leadership by a great power is a necessary condition for global order and governance. Moreover, it often relies on the zero-sum assumption that the world is a closed system with a fixed amount of leadership and power, where the leadership of one state detracts from that of another (for this view, see Yan 2016). The assumption is that 'global leadership' is a distinct and fixed role out there — a 'mantle to pick up' or 'void to fill' — which a declining power finds it increasingly difficult to assume while a rising power is able to take more and more of these roles (the provision of public goods, for example). However, what if global leadership is not a mantle 'out there' to lay down, pass on, or take up, but rather that the very nature of global order, governance and leadership is changing? Instead of discussing American versus Chinese leadership, will leadership in the years to come be increasingly regional, fragmented, and ad-hoc? Several of the theoretical contributions in the first special issue (titled "International Leadership and Global Governance," Chinese Political Science Review, vol. 2, no. 4,2017 ) explored these more fundamental transformations of global governance and leadership. The contributions by Ole Wæver and Shaun Breslin, for example, each make sense of the fragmentation of global leadership in a 'non-polar' world with 'no superpowers', concluding - albeit cautiously - that some semblance of order can be drawn from the current sense of instability and disorder, but that future models of leadership will be more ad-hoc, varying across issue areas. For Wæver, this is driven by the forces of survival, identity, and competition, while Breslin points to functionalist dynamics that create space for non-state actors to also play a leadership role.

Moreover, it is far from obvious that China is capable and willing to lift the burden of global leadership, its leadership rhetoric notwithstanding. As Peter Marcus Kristensen's analysis of US narratives on global leadership highlighted, concerns about a 'Thucydides trap', in which the incumbent leader's fear of a rising challenger makes war inevitable (Allison 2017), are giving way to speculation about a 'Kindleberger trap' ${ }^{5}$ in which the United States has abdicated global responsibility before China is ready and willing to provide global public goods. Mark Beeson, who finished off the first issue, tackles this phenomenon empirically, identifying a "leadership gap" in East Asia that has been intensified by President Trump's transactional foreign policy style, and argues that a rising China may (although has not yet) come to play a decisive leadership role in the region.

\footnotetext{
5 Joseph S. Nye, 2017. “The Kindleberger Trap”, https://www.project-syndicate.org/commentary/trumpchina-kindleberger-trap-by-joseph-s-nye-2017-01?barrier=accessreg.
} 


\section{Leadership with Chinese Characteristics}

These debates prompt two fundamental questions about China's international leadership role, which are confronted in this special issue. First, can and will China lead? In addition, second, if yes, how will China lead?

In response to the first question, Chen Zhimin et al. start off this special issue with an emphatic 'yes', arguing that failure to take on an international leadership role would be both a shirking of responsibility and a waste of opportunity. In answering the second question, they put forward the concept of "facilitative leadership" by China. A type of leadership that is cooperative, attractive, mutually beneficial and empowering, aiming to deliver effective international cooperation in an era of global urgency-much in line with official Chinese policy of "nonconflict, non-confrontation, mutual respect and win-win cooperation." This article is the latest in an emerging Chinese literature that seeks to develop a conceptual and theoretical framework on 'leadership with Chinese characteristics' — whose primary distinctiveness is that it is different from US hegemonic leadership style (see e.g. Yan 2011a, b). Both the Chen et al. paper and the Moral Realist approach of Yan Xuetong and the Tsinghua School stresses the importance of virtuous, moral, consensual and benevolent leadership rather than leadership by force. While they tend to stress the 'Chineseness' of such concepts, they actually read quite well alongside Zhang Biao's contribution to the first special issue, in which he uses the ('Western') classical realist theory of Hans Morgenthau to assess Donald Trump's leadership virtues, stressing the importance of wisdom, foresight, judgment, prudence, willingness, determination, courage, restraint, skill, leadership, governance and persuasion.

Contemporary attempts to construct a Chinese approach to leadership direct our attention to the contingency and cultural variability in the very conception of what global leadership is and should be. Global leadership clearly does not mean the same to different prospective global leaders and their conceptions of leadership are sometimes mutually exclusive. For example, hegemony carries much more negative connotations in Chinese IR discourse than it does in Western-American discourse. Moreover, these culturally informed conceptions of global leadership are often tied to particular (exceptionalist) identity discourses by which great powers justify their newfound global leadership. American global leadership, for example, has often been justified by an exceptionalist discourse where America is 'bound to lead', has a special and 'indispensable' leadership role and is the only country that can lead by example and attraction rather than force. In European foreign policy circles, it has also long been argued that Europe is a different kind of power, a 'normative power' that leads by diffusing its norms and shaping conceptions of what is normal in international relations. Some argue that China's authoritarian political system precludes the cultivation of this kind of attractive power that is so crucial to international leadership (Shambaugh 2013). Yet, even though both American and European leadership discourse stresses the importance of leading by example, and using soft and normative power, Chinese discourses on leadership nonetheless 
present China's virtuous and exemplary approach to leadership as very different from Western leadership style.

This special issue has only opened the question of Chinese conceptions-and not least contentions-over global leadership. Further research is needed on the ongoing debates in Chinese foreign policy thinking as this is a key vector affecting the direction and magnitude of China's future leadership project. Moving away from the more academic and elite conceptions of leadership within China, it is equally important to examine the domestic support or resistance to leadership projects because it affects both the willingness and ability to lead, and thus the magnitude and direction it will take. The Burzo and Li article aims to fill this gap. They provide original data on public perceptions of international leadership in China and the United States, raising the paradox that-while Chinese leaders ${ }^{6}$ and scholars (including the article by Chen et al. in this special issue) advocate plural, collective, leadership, many Chinese citizens appear to believe that leadership can only be provided by one power. Does this contradiction impede Chinese facilitative and collective leadership? The interaction between China's elite and public conceptions of global leadership and responsibilities will provide a key to China's future leadership.

As Ole Wæver and Chen Zhimin pointed out in the introduction to the first of these two special issues, scholarship on international leadership has tended to focus either on powerful states or important individual leaders - the statesman. However, when and where China can and will lead, and what Chinese leadership would look like, depends not just on state or elite support, but also on the complex dynamics of domestic interest groups-including bureaucracies, business, civil society and the wider public (Shirk 2007). Domestic vectors can affect China's global leadership projection not only by affecting domestic 'capacity building' for global leadership (economic, military, political resources) but also because domestic challenges to regime legitimacy (e.g. pollution or laggard growth) are likely to direct China's global leadership project in certain directions and not others. For example, China's decision to take a prominent role in international climate leadership may be as much a function of domestic environmental and energy pressures as a desire to contribute internationally. Other papers also stress the domestic vectors of China's leadership project. Using the case of China-IMF cooperation to analyze China's role in international financial leadership, Wang Jue illuminates the impact of Chinese domestic interest groups' evolving objectives on their central government's interaction with international organizations. This article contributes to a distinguished literature on China's fragmented authoritarian structure, in which the interests of decentralized decision makers can distort central goals (Lieberthal and Oksenberg 1988; Lieberthal and Lampton 1992).

Another key theme in the special issue is that China's global leadership project is likely to play out very differently in different sectors of global governance (traditional as well as non-traditional security, peacekeeping, trade, development,

\footnotetext{
${ }^{6}$ See e.g. remarks by China's Foreign Minister Wang Yi in March 2017: Xinhua, 2017. "FM: China, U.S. can avoid Thucydides Trap, Kindleberger Trap", 20 March. http://news.xinhuanet.com/english/ 2017-03/20/c_136143525.htm.
} 
finance, and human rights) and at different levels (ranging from domestic-regionalglobal). In some sectors and at some levels, China seems proactive and bold, but in others, it remains cautious. It is both tao guang yang hui (keeping a low profile) and feng fa you wei (striving for achievements) (Qin 2014). At present, China's leadership is nascent and confined to specific sectors such as climate change and infrastructure development. Geographically, it is concentrated in Asia Pacific, although the Belt and Road Initiative (BRI) indicates an intention to extend across Central and South East Asia, Europe, and East Africa. However, even in East Asia-China's historical sphere of influence-it has refrained from challenging US security alliances.

Three articles in this special issue tackle the question of sectors and levels in China's current approach to leadership. In terms of regional security, for example, China's economic growth and corresponding military modernization, arms buildup, and revisionist territorial ambitions lead to what Sun Xuefeng calls the "rise dilemma". The "rise dilemma" has led China to take a state-by-state approach to East Asian security, with Chinese strategies ranging from tight strategic support for countries such as Russia and Indonesia, to uniting with the United States to manage security "red lines" vis-à-vis states such as Japan, who have strong concerns about China's rise. Traditional security is an interesting sector to study Chinese leadership, because China is both seen as doing too much ('China Threat', 'assertiveness', and artificial island building in the South China Sea) and too little (Syria, non-proliferation, North Korea) (Huotari et al. 2017). Overall, however, regional security remains the one area, where Chinese leadership is probably least welcomed by others. Beyond the region, Chinese leadership is slightly more welcomed. For example, China is now the second-largest contributor to UN peacekeeping missions. This has been interpreted as a way for China to provide global public goods and thus demonstrate its "responsible Great Power" status (Foot 2014).

Linking the regional and global level, $\mathrm{Pu}$ Xiaoyu asks why China seeks active regional leadership, but is reluctant to take on a global leadership role. He uses the concept of "status shopping" to explain why China is unwilling to abandon its position as a developing country and take on global responsibilities that may bring more costs than benefits. Zooming out to the global level, Andrew Cooper and Zhang Yanbing analyze China's dualistic "inside-outsider" approach to global institutions, which allows China to simultaneously preserve solidarity with the developing world and build its international status. Their article moves beyond the simplistic revisionist vs. status quo framing of most power transition literature, in which China either integrates into the American-led liberal order (status quo), attempts to revise (revisionist) or even overthrow it and replace it with a new Chinaled order (revolutionist). Instead, they argue that China is doing both at once, integrating as well as constructing a new order, which points towards the possibility that the 21 st century may neither be another American century nor a Chinese one, but an era of many world orders-what Amitav Acharya calls a "multiplex world" (Acharya 2017).

Another key theme that underpins these three articles (either explicitly or implicitly) is flexibility. China seeks (or accepts) leadership responsibility, where it 
is practicable and beneficial for China's national interest-and particularly for regime security - to do so, and steps into the background when it is not. This approach to international leadership parallels China's strategy for its own economic modernization, which has long been noted for its flexible, experimental, and pragmatic approach of mo zhe shi tou guo he (crossing the river while feeling the stones). Through exploring the vectors that determine whether and in what contexts China pursues tao guang yang hui (keeping a low profile) or feng fa you wei (striving for achievements), the Sun, Pu, and Cooper and Zhang articles offer nuance to a contested debate within the literature on whether China under $\mathrm{Xi}$ Jinping has become increasingly proactive and leaderly (Yan 2014; Qin 2014)—or "assertive" as has been the preferred term in the Western discourse. ${ }^{7}$

\section{A Great Lead Forward?}

To sum up, these two special issues were prompted by the apparent decline of US global leadership, the questions this raised about an international leadership vacuum, and whether and how China might fill this vacuum. The world's most pressing problems spanning from climate change, economic crises, mass migration, the growing shortage of drinkable water, biosecurity threats, terrorism, and nuclear proliferation may benefit from what Chen et al. conceptualize as "facilitative" rather than coercive leadership. However, as the remaining articles in this special issue illuminate, whether, when and where China is likely to provide such leadership is determined not only by the amount of global problems 'out there' that call for leadership, or China's status seeking or attempt to reassure neighbours that it will avoid the so-called 'Thucydides trap', but also by complex domestic variables.

Rather than a great leap forward, these two special issues arguably raise more questions about leadership than they answer. Several of these call for further study. For example, what are the main vectors that affect willingness and capability for global leadership? Particularly, what are the domestic vectors (public opinion, domestic political and economic needs, the interests of various groups within society, and so on); and what are the international ones (ability to attract followership and to gain recognition from existing powers, etc.) that determine when and where a state takes on leadership responsibilities? This second category of research questions aims at systematizing the complex international and domestic set of variables alluded to in this special issue on China's international leadership.

Moreover, on what issues will China (or other powers) lead? In other words, what are the main sectors or themes in which we are likely to see more leadership from particular countries - and those where we will not? What are the factors determining why states elect to lead on particular issues (national interest, reputational concerns, normative values, domestic interest groups, and so on)? For example, why does China choose to lead on economic globalization but not on the North Korean

\footnotetext{
${ }^{7}$ M Taylor Fravel, 2012. "Revising Deng's Foreign Policy", The Diplomat. http://thediplomat.com/ 2012/01/revising-dengs-foreign-policy-2/.
} 
nuclear problem? Why does Europe take the lead on climate change but not on mass migration?

The American-led international order is in flux, and what comes next is still uncertain. These two special issues reach a tentative conclusion that-in the absence of a single global leader-collaboration remains possible, but may be more issuespecific and flexible. That China will play an important role in this seems inevitable, but what exactly that role will look like remains unclear. Innovative answers to these questions demand fresh approaches that bring together theories, philosophies, and experiences from Western and Chinese scholars, and from scholars of new and established generations. These two special issues are the result of a joint effort from scholars across four continents, and from graduate students up to some of the most distinguished scholars in the field. We hope these contributions will stimulate more collaborative study on the many urgent and unanswered questions of international leadership.

\section{References}

Acharya, Amitav. 2017. After liberal hegemony: the advent of a multiplex world order. Ethics and International Affairs 31 (3): 271-285.

Allison, Graham. 2017. Destined for war: can America and China escape Thucydides's trap? Boston: Houghton Mifflin Harcourt.

Foot, Rosemary. 2014. 'Doing some things' in the Xi Jinping era: the United Nations as China's venue of choice. International Affairs 90 (5): 1085-1100.

Huotari, Mikko, Jan Gaspers, Thomas Eder, Helen Legarda, Sabine Mokry. 2017. China's Emergence as a Global Security Actor: Strategies for Europe. MERICS papers on China. https://www.merics. org/fileadmin/user_upload/downloads/MPOC/MPOC_04_Security/170705_MPOC_04_China_s_ Emergence_as_a_Global_Security_Actor_Web.pdf. Accessed 1 December 2017.

Lieberthal, Kenneth, and David M. Lampton. 1992. Bureaucracy, politics, and decision making in postMao China. Oxford: University of California Press.

Lieberthal, Kenneth, and Michel Oksenberg. 1988. Policy making in China: leaders, structures, and processes. Princeton: Princeton University Press.

Qin, Yaqing. 2014. Continuity through Change: Background Knowledge and China's International Strategy. The Chinese Journal of International Politics 7 (3): 285-314.

Shambaugh, David. 2013. China goes global: the partial power. Oxford: Oxford University Press.

Shirk, Susan L. 2007. China: fragile superpower. Oxford: Oxford University Press.

Yan, Xuetong. 2011a. Ancient Chinese thought, modern Chinese power. Princeton and Oxford: Princeton University Press.

Yan, Xuetong. 2011b. International leadership and norm evolution. Chinese Journal of International Politics 4 (3): 233-264.

Yan, Xuetong. 2014. From Keeping a Low Profile to Striving for Achievement. Chinese Journal of International Politics 7 (2): 153-184.

Yan, Xuetong. 2016. Political leadership and power redistribution. The Chinese Journal of International Politics 9 (1): 1-26.

Zeng, Jinghan. 2017. Does Europe Matter? The role of Europe in Chinese narratives of 'one belt one road' and 'new type of great power relations': the role of Europe in Chinese narratives. JCMS Journal of Common Market Studies 55 (5): 1162-1176.

Peter Marcus Kristensen, PhD is an Associate Professor at the Department of Political Science, University of Copenhagen. His main fields of research are rising powers and power transitions, nonWestern perspectives on international relations, and the sociology of international thought. He wishes to 
thank his students in the course 'Re-Orienting International Relations: Asian Perspectives on World Politics' for their excellent comments on the special issue and suggestions for how to move this research agenda forward.

Pippa Morgan is a PhD Candidate at the School of International Relations and Public Affairs (SIRPA), Fudan University. She is the Assistant Editor of the Chinese Political Science Review and the Fudan Journal of the Humanities and Social Sciences. Her research focuses on Chinese foreign policy, international political economy, and China-Africa relations. 